\title{
Transformability of Haemophilus influenzae
}

\author{
By J. H. STUY \\ Philips Research Laboratories, N.V. Philips' Gloeilampenfabrieken, \\ Eindhoven, Netherlands
}

(Received 8 March 1962)

SUMMARY

\begin{abstract}
A method is described for the preparation of highly competent (transformable) bacteria of Haemophilus influenzae. After three successive treatments, i.e. aerobic growth, anaerobic incubation and incubation in saline containing a few per cent broth, transformation frequencies close to $5 \%$ have been obtained.

Competent bacteria absorb DNA very fast. Untransformable ones lack this ability. Absorption is inhibited by dinitrophenol or arsenate; it is not inhibited by chloramphenicol. This suggests the participation of an enzyme system.

Development of competency is blocked by dinitrophenol, arsenate or chloramphenicol. It is strongly dependent upon temperature. It is not influenced by the absorption of one or two DNA molecules per bacterium.
\end{abstract}

\section{INTRODUCTION}

Bacterial transformation is that process in which bacteria acquire new genetic characteristics by means of absorption and incorporation of homologous deoxyribonucleic acid (DNA, usually derived from a mutant clone) (Avery, MacLeod \& McCarty, 1944). Bacteria are called competent if they can undergo transformation. It is not understood what makes them competent. However, it must involve adsorption of the DNA on to the cell wall, its transport through the bacterial membrane to the nuclear aggregate and some way of incorporation into the bacterial genome. Hotchkiss (1954) studied it in Diplococcus pneumoniae and showed that it might be related to its normal growth cycle. Chloramphenicol inhibited the development of competency (Fox \& Hotchkiss, 1957). S. H. Goodgal \& R. M. Herriott (pers. comm. 1958) obtained competent cultures of Haemophilus influenzae through interruption of the aerobic growth of a culture by a period of more or less anaerobic incubation. This was recently described in detail (Goodgal \& Herriott, 1961). Stuy (1960), however, pointed out that holding aerobically grown bacteria (in vigorously shaken suspensions) under conditions excluding oxygen nearly completely, was merely a 'pretreatment'. It had to be followed by incubation in media which support growth poorly at best (such as saline plus a few per cent broth) in order to obtain transformation frequencies greater than one per cent. This process has been studied by us in more detail, the results of which are reported below. 


\section{METHODS}

Growing of cultures, preparation of media and of DNA, and transformation techniques (Stuy, 1961 $a, b$ ) were modified as follows. Stock cultures were maintained at room temperature as stab-cultures in Levinthal agar. Plating agar consisted of one volume each of Levinthal Stock (Difco Brain Heart Infusion supplemented with hemin and DPN) and Eugon broth (Baltimore Biological Laboratories) mixed with $1.75 \%$ Bacto agar (Difco). This agar is very clear, facilitating colony counting after $20 \mathrm{hr}$. of incubation. Competent bacteria were exposed to DNA $\left(2 \times 10^{8}\right.$ viable centres $/ \mathrm{ml}$. in a total of $2 \mathrm{ml}$.) while gently shaken at room temperature. The time of exposure was generally limited to $5 \mathrm{~min}$. when the DNA was present in excess (more than $0 \cdot 1 \mu \mathrm{g} . / \mathrm{ml}$.). The bacteria were in those cases diluted into Eugon broth containing $5 \mu \mathrm{g} . / \mathrm{ml}$. of DNase (Worthington Laboratories) and incubated for at least 5 min. Transformants were scored by seeding proper dilutions in a total of $5 \mathrm{ml}$. of agar, followed by $2 \mathrm{hr}$. of incubation at $37^{\circ}$ (which period allows complete expression of the DNA incorporated) and then relayered with antibioticcontaining agar.

Transformation frequencies were calculated by dividing the numbers of transformants by the numbers of colony-forming units. Unless stated otherwise, the latter was only occasionally determined as it was always found to be about $2 \times 10^{8}$ per $\mathrm{ml}$. The actual frequencies are estimated to be lower by about $30 \%$ due to the fact that competent cultures do not exclusively contain single bacteria.

The wild type strain Rd of Haemophilus influenzae (obtained from Miss Grace Leidy, New York) was used as the recipient test strain. It is sensitive to $3 \mu \mathrm{g}$. streptomycin $/ \mathrm{ml}$., $0 \cdot 3 \mu \mathrm{g}$. cathomycin $/ \mathrm{ml}$. (novobiocin) and $1 \mu \mathrm{g}$. erythromycin $/ \mathrm{ml}$. The genetic markers employed: SM, Ca and Ery 6, conferred resistance on the recipient bacteria to, respectively, more than $2 \mathrm{mg}$. streptomycin $/ \mathrm{ml} ., 5 \mu \mathrm{g}$. cathomycin $/ \mathrm{ml}$. and $6 \mu \mathrm{g}$. erythromycin $/ \mathrm{ml}$. (Stuy, 1961 a). DNA carrying these markers was extracted from the strains $\mathrm{Rd} / \mathrm{SM}, \mathrm{Rd} / \mathrm{Ca}$ and $\mathrm{Rd} / \mathrm{Ery} 6$ and is designated DNA(SM), DNA(Ca) and DNA(Ery 6), respectively.

Standard saline contained $0 \cdot 15 \mathrm{M}-\mathrm{NaCl}$. Chloramphenicol was used at a concentration of $10 \mu \mathrm{g} . / \mathrm{ml}$.

Aerobic growth of cultures was carried out by vigorously shaking $15 \mathrm{ml}$. at $37^{\circ}$ in a $125 \mathrm{ml}$. flask having a side-arm. When the turbidity of the culture at $5900 \AA$ (measured in the $18 \mathrm{~mm}$. side-arm) had reached a value of $0 \cdot 35-0.40\left(1 \times 10^{9}\right.$ viable centres $/ \mathrm{ml}$.) the $15 \mathrm{ml}$. of culture were poured in the side-arm (length of column about $6 \mathrm{~cm}$.) and incubation at $37^{\circ}$ was now continued without shaking. After $75 \mathrm{~min} .0 .2 \mathrm{ml}$. of the culture were added to $1.6-1.8 \mathrm{ml}$. of saline in a $25 \mathrm{~mm}$ tube and incubated at $30^{\circ}$. Nearly all bacteria can be shown to have become competent after about $60 \mathrm{~min}$. at this temperature.

\section{RESULTS}

\section{Absorption of $\mathrm{DNA}$}

As will be shown, highly competent (transformable) bacteria are obtained only after three successive treatments: aerobic growth to about $10^{9}$ colony-forming centres per ml., more or less anaerobic incubation in the same broth (anaerobically 
held or sensitized) and incubation in a 'non-growth' medium. We will describe the effects of variations in either step.

The actual process of DNA absorption by the bacteria can be of great importance with respect to drawing of sound conclusions. We presumed that the observed responses to exposure of test cells to genetically marked DNA (numbers of transformants detected) can under certain conditions be used to study the kinetics of the absorption proper. This was done first.

Kinetics. Competent bacteria $\left(2 \times 10^{8}\right.$ per ml., see below) were mixed with DNA and gently shaken at room temperature $\left(23^{\circ}\right)$ in a gyratory shaker. Samples were withdrawn at intervals, exposed to DNase and transformants scored. Figure 1 demonstrates that DNA absorption (leading to transformation) is virtually completed by the tenth min. in the presence of excess DNA. Limiting amounts take more time to be absorbed completely, depending upon concentration of bacteria and DNA. The rate of DNA absorption is very high and this justifies the short exposure time of 5 min. generally employed in cases of excess DNA.

Inhibition. Competent bacteria were spun down and resuspended in the media to be investigated. The rate of DNA absorption (excess DNA, 5 min. exposure time) was not or little influenced by saline, saline plus $10 \%$ Levinthal broth, Levinthal broth, Eugon broth, saline containing chloramphenicol, ammonium chloride or sodium acetate (both $1 \mathrm{~g} . / 100 \mathrm{ml}$., buffered at $\mathrm{pH} 7.0$ with Tris); $\mathrm{pH}$ variations from 6.5 to $7 \cdot 5$ had little effect. From 50 to $90 \%$ inhibitory were $10^{-4}$ to $10^{-3} \mathrm{M}$ 2,4-dinitrophenol, sodium arsenate in ratios to phosphate present from 1 to 10 (see controls in Table 3) and ammonium acetate as the only electrolyte (tested from 0.5 to $2.0 \mathrm{~g}$. $/ 100 \mathrm{ml}$.). Inhibition by dinitrophenol was readily reversed by diluting it out. It was not reversed by $10^{-3}$ or $10^{-2} \mathrm{M}$-adenosine triphosphate.

\section{Incubation in non-growth medium}

Development of competency. The development of competency in such a medium was demonstrated in the following experiment. Anaerobically held bacteria (see below) were diluted ten fold into buffered saline (with phosphate at pH 7.0). A series of duplicate tubes was incubated at $30^{\circ}$. At the times stated, excess DNA was added to one culture and the transformants scored after $5 \mathrm{~min}$. Chloramphenicol was added to the other culture and incubation was continued. At $60 \mathrm{~min}$. all remaining cultures were exposed to excess DNA and transformants scored. It can be seen in Table 1 that at time zero the cultures contained very few competent (transformable) bacteria but that they became highly competent upon incubation. Chloramphenicol halted the development completely (the small drops in transformants are probably due to the observed 30 to $50 \%$ killing by the antibiotic) except in the zero-time culture where it allowed some increase. It did not at all interfere with the absorption of the DNA by the bacteria. Nor did it reduce the rate of marker expression in the $2 \mathrm{hr}$. period at $37^{\circ}$ at the proper concentration as was established in a separate experiment.

Influence of temperature. A more refined experiment is presented in Fig. 2. An anaerobically held culture was diluted ten-fold in ice-cold saline. Samples $(1.8 \mathrm{ml}$.) were put in variously thermostated water baths at time zero. Chloramphenicol and excess DNA(SM) were added together at indicated times. Trans- 
formants were scored after $10 \mathrm{~min}$. of exposure at room temperature. Since chloramphenicol stops the development of competency, a set of proper curves was obtained which describe this development at various temperatures. It is shown in Fig. 2 that anaerobically held bacteria become competent at rates which depend strongly upon temperature. At a low temperature of $14.5^{\circ}$ there is no development at all. It should be pointed out here that turbidity measurements showed some growth at $35^{\circ}$ and at $37^{\circ}$ but none at $30^{\circ}$ or lower temperatures. The decreased numbers of viable centres at the lower temperatures are probably due to the death of some of the (cold-sensitive) bacteria.

Table 1. Development of competency at $30^{\circ}$

An anaerobically held culture was diluted ten-fold into tubes containing $0 \cdot 1$
Chloramphenicol was added at a final concentration of $10 \mu \mathrm{g}$. $/ \mathrm{ml}$. after 0 ,
60 min. In the first series of tubes, transformants were scored immediat
exposure during 5 min. to $0.8 \mu \mathrm{g}$./ml. (excess) of DNA(SM)). In the second
tubes, transformants were scored after incubation at $30^{\circ}$ had been continued up
$\begin{array}{ccc}\text { Time of incubation } & \text { Transformants } & \text { Viable count } \\ \text { at } 30^{\circ} \text { (min.) } & \text { per ml. } & \text { per ml. } \\ 0 & 2 \cdot 5 \times 10^{3} & - \\ 0 \text { to } 60 \text { plus chl. } & 8 \cdot 0 \times 10^{3} & 1 \cdot 5 \times 10^{8} \\ 15 & 5 \cdot 5 \times 10^{5} & - \\ 15 \text { to } 60 \text { plus chl. } & 2 \cdot 7 \times 10^{5} & - \\ 30 & 1 \cdot 9 \times 10^{6} & - \\ 30 \text { to } 60 \text { plus chl. } & 9 \cdot 3 \times 10^{5} & - \\ 60 & 3 \cdot 1 \times 10^{8} & 2.0 \times 10^{8} \\ 60 \text { plus chl. } & 2 \cdot 8 \times 10^{6} & 2 \cdot 0 \times 10^{8}\end{array}$

Chemical requirements. The 'non-growth' medium can be varied in a number of ways. We have studied the influence of decreasing broth concentrations (Table 2). Below a 300-fold dilution, the transformation frequency drops. These results are in good agreement with those by Grace Leidy (in the press). She established that the chemical requirements for the development of competency were aspartate or glutamate in phosphate-buffered saline plus calcium and magnesium ions. We confirmed this (Table 2) except that $\mathbf{M g}^{2+}$ was not required. However, it may have been present as an impurity in the calcium chloride used. In addition to the above chemicals, we found that oxygen is also needed.

Metabolic inhibitors. An anaerobically held culture was diluted ten-fold into saline containing increasing amounts of the poisons studied and incubated at $30^{\circ}$ during $60 \mathrm{~min}$. before addition of excess DNA. The effective inhibitors were active at concentrations which just blocked normal aerobic growth. At the highest concentrations used, roughly $\mathbf{5 0} \%$ of the viable centres had been killed. The results are presented in Table 3. It is pointed out that the observed effects are several orders greater than those found on DNA absorption.

Influence of DNA itself. Absorbed DNA might in some way block the subsequent absorption of more DNA. This phenomenon could then partly explain why excess DNA has a saturating effect. We have studied this problem in two series of experiments. First, anaerobically held bacteria were diluted ten-fold into saline (to make them competent) containing increasing amounts of DNA(Ery 6). The second culture contained one DNA molecule per Rd bacterium $(0.006 \mu \mathrm{g} . / \mathrm{ml}$. $)$, the third 
culture two, the fourth culture four and the fifth culture eight. The first culture contained no DNA. It was assumed that upon preparation of the DNA from the donor cells, it was broken up into some 100 different particles, one of which carried the Ery 6 marker (Goodgal \& Herriott, 1957; Stuy, 1961 $a$ ). After 60 min. at $30^{\circ}$, excess DNA(SM) was added. Ery 6- and SM-transformants were scored after 5 min. of exposure. It is clear from Table 4 that the predictably absorbed DNA(Ery 6) had little or no effect on the subsequent response to the exposure to DNA(SM).

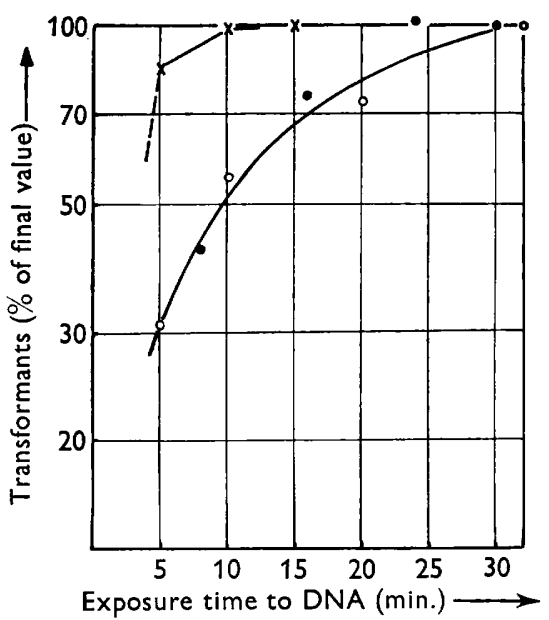

Fig. 1

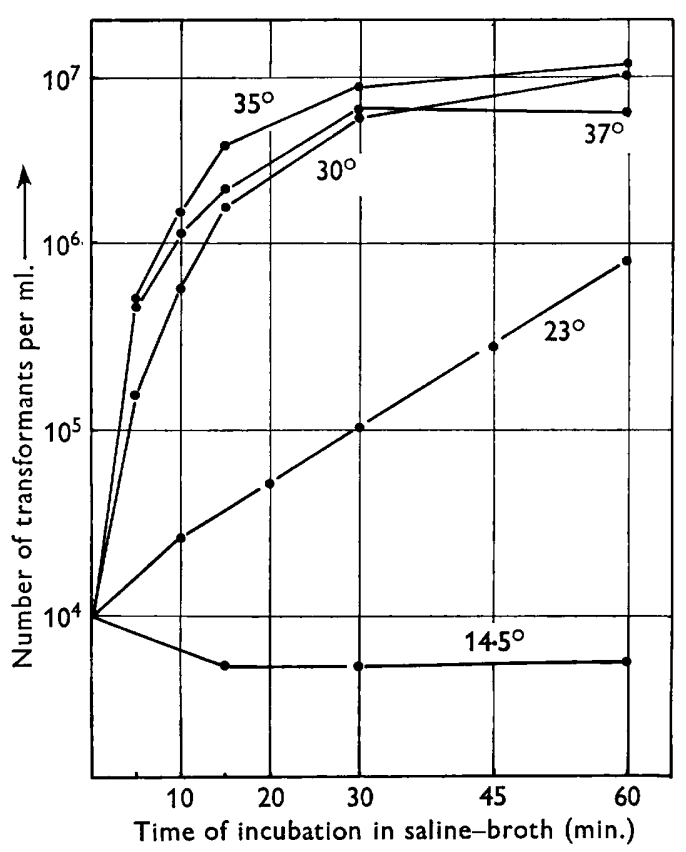

Fig. 2

Fig. 1. Rate of DNA absorption by competent bacteria of Haemophilus influenzae strain Rd $\left(2 \times 10^{8}\right.$ per ml. $)$. Medium: saline plus $10 \%$ broth. DNA was added to the suspensions and the mixtures gently shaken at room temperature. Transformants were scored at intervals. It is presumed that the absorption of the DNA is the rate-limiting step of the effect observed. Crosses : excess DNA, $0 \cdot 4 \mu \mathrm{g} . / \mathrm{ml}$.; final value, $5 \cdot 0 \times 10^{6}$ transformants per ml. Open circles: limiting amount of DNA(SM), 0.004 $\mu \mathrm{g} . / \mathrm{ml}$; ; final value, $9 \cdot 0 \times 10^{5}$. Filled circles : limiting amount of DNA(Ery 6$)$ in the presence of chloramphenicol, $0 \cdot 001 \mu \mathrm{g} . / \mathrm{ml}$; final value, $1 \cdot 7 \times 10^{5}$.

Fig. 2. Development of competency in Haemophilus influenzae strain Rd during incubation in saline plus $10 \%$ broth at various temperatures. An anaerobically held (sensitized) suspension was diluted ten-fold in series of tubes with saline pre-warmed at the indicated temperatures. Chloramphenicol and $0.8 \mu \mathrm{g} . / \mathrm{ml}$. (excess) of DNA(SM) were added after intervals and transformants scored after $10 \mathrm{~min}$. Viable counts times $10^{-8}$; after $90 \mathrm{~min}$., $14.5^{\circ} ; 1.3$ and $23^{\circ}: 1.8$; after $60 \mathrm{~min} ., 30^{\circ}: 2 \cdot 2,35^{\circ}: 2.7$ and $37^{\circ}: 2.9$. Transformants at $23^{\circ}$ after 90 min. : $1.5 \times 10^{6}$.

Excess amounts of DNA were used in the second series of experiments. At time zero, $0.47 \mu \mathrm{g} . / \mathrm{ml}$. of DNA(Ca) was added to a series of highly competent Rd cultures. Transformants were scored at intervals after which $0 \cdot 8 \mu \mathrm{g} . / \mathrm{ml}$. of DNA(SM) was added. Ca-, SM- and (SM-Ca)-transformants (doubles) were assayed after 5 min. DNA (SM) alone and a mixture of two DNAs were also added to two 


\section{Table 2. Chemical requirements of the development of competency in phosphate-buffered saline}

Anaerobically held bacteria were incubated at $30^{\circ}$ in the media given below during $60 \mathrm{~min}$. after which $0.8 \mu \mathrm{g} . / \mathrm{ml}$. of DNA(SM) was added. Time of exposure was 5 min. The transformation frequencies were actually determined. Viable centres had dropped to about one-half in broth dilutions lower than 1/1000. Anaerobic conditions during incubation at $30^{\circ}$ : bacteria were diluted in cold saline in a tube carrying a side-arm containing chromochloride. The tube was evacuated in the cold and then incubated at $30^{\circ}$ during $60 \mathrm{~min}$. Hereafter, the culture was chilled again and air was admitted. Chloramphenicol was added and then DNA. A similarly treated aerobic culture (no air evacuation) served as a control.

\begin{tabular}{|c|c|c|}
\hline $\begin{array}{c}\text { Saline } \\
\text { dilution }\end{array}$ & Addition & $\begin{array}{l}\text { Transformation } \\
\text { frequency }\end{array}$ \\
\hline 10 & None & $2 \cdot 1 \times 10^{-2}$ \\
\hline 30 & None & $2 \cdot 3 \times 10^{-2}$ \\
\hline 100 & None & $1.7 \times 10^{-2}$ \\
\hline 300 & None & $9.0 \times 10^{-8}$ \\
\hline 1,000 & None & $6.8 \times 10^{-4}$ \\
\hline 3,000 & None & $2 \cdot 3 \times 10^{-4}$ \\
\hline 10,000 & None & Less than $10^{-4}$ \\
\hline 10,000 & 0.03 volume of broth & $1.3 \times 10^{-2}$ \\
\hline 10,000 & $0.01 \mathrm{M}-\mathrm{Mg}, 0.01 \mathrm{M}-\mathrm{Ca}$ & $1.6 \times 10^{-3}$ \\
\hline 10,000 & $0.5 \%$ aspartate, $\mathrm{Mg}$ & $5.5 \times 10^{-8}$ \\
\hline 10,000 & Aspartate, $\mathrm{Ca}$ & $1.3 \times 10^{-2}$ \\
\hline 10,000 & Aspartate, $\mathrm{Mg}, \mathrm{Ca}$ & $1.5 \times 10^{-2}$ \\
\hline 10 & None, anaerobic & $1.8 \times 10^{-8}$ \\
\hline
\end{tabular}

Table 3. Effect of cell poisons on the development of competency and on DNA absorption

Anaerobically held bacteria were diluted ten-fold into tubes containing saline and the indicated poisons. They were incubated at $30^{\circ}$ during $60 \mathrm{~min}$. after which $0.8 \mu \mathrm{g} . / \mathrm{ml}$. of DNA(SM) was added. Transformants were scored after 5 min.

Cell poison

None

Chloramphenicol 0.1 $\mu \mathrm{g} . / \mathrm{ml}$. $1.0 \mu \mathrm{g} . / \mathrm{ml}$. $10 \mu \mathrm{g} . / \mathrm{ml}$.

added with DNA,* $10 \mu \mathrm{g} . / \mathrm{ml}$.

Dinitrophenol 10-5

$10^{-4}$

$10^{-8}$

Added with DNA,* $10^{-3} \mathrm{M}$

Arsenate: phosphate $0 \cdot 1 \dagger$

$1 \cdot 0$

10

Added with DNA,* 10
Transformants per ml.

$5.2 \times 10^{8}$

$5 \cdot 1 \times 10^{6}$

$7 \cdot 8 \times 10^{5}$

$1.0 \times 10^{4}$

$5.6 \times 10^{6}$

$5.3 \times 10^{6}$

$4.0 \times 10^{6}$

$3.4 \times 10^{3}$

$9.0 \times 10^{5}$

$3.7 \times 10^{6}$

$4.7 \times 10^{5}$

$4.6 \times 10^{4}$

$1.4 \times 10^{6}$
Viable centres per $\mathrm{ml}$.

$2.2 \times 10^{8}$
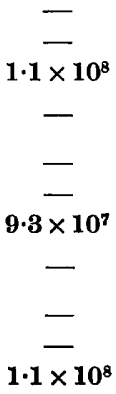

$1.1 \times 10^{8}$

* The poisons were added together with the DNA in a control tube in order to determine their effect on the DNA absorption proper.

$\dagger$ Arsenate concentration: $12 \mu \mathrm{g} . / \mathrm{ml}$. 
Table 4. Effect of exposure of competent bacteria to limiting amounts of DNA on the subsequent response of exposure to excess DNA

An anaerobically held $\mathrm{Rd}$ culture was diluted ten-fold in saline containing increasing amounts of DNA(Ery 6). $0.8 \mu \mathrm{g} . / \mathrm{ml}$. of DNA(SM) was added after $60 \mathrm{~min}$. at $30^{\circ}$. Transformants were scored after $5 \mathrm{~min}$.

\begin{tabular}{|c|c|c|c|}
\hline Amount of DNA(Ery 6) & $\begin{array}{c}\text { Transformants } \\
\text { scored }\end{array}$ & Number per ml. & Total \\
\hline No DNA(Ery 6) & SM & $5.2 \times 10^{6}$ & $5.2 \times 10^{8}$ \\
\hline $\begin{array}{l}1 \text { molecule per } \\
\text { bacterium }(0 \cdot 006 \mu \mathrm{g} . / \mathrm{ml} \text {.) }\end{array}$ & $\begin{array}{l}\text { Ery } 6 \\
\text { SM }\end{array}$ & $\left.\begin{array}{l}8 \cdot 1 \times 10^{5} \\
5 \cdot 5 \times 10^{8}\end{array}\right\}$ & $6 \cdot 3 \times 10^{6}$ \\
\hline $\begin{array}{l}2 \text { molecules per } \\
\text { bacterium }\end{array}$ & $\begin{array}{l}\text { Ery } 6 \\
\text { SM }\end{array}$ & $\left.\begin{array}{l}1.9 \times 10^{6} \\
5.1 \times 10^{6}\end{array}\right\}$ & $7.0 \times 10^{6}$ \\
\hline $\begin{array}{l}4 \text { molecules per } \\
\text { bacterium }\end{array}$ & $\begin{array}{l}\text { Ery } 6 \\
\text { SM }\end{array}$ & $\left.\begin{array}{l}3.3 \times 10^{6} \\
4.1 \times 10^{6}\end{array}\right\}$ & $7 \cdot 4 \times 10^{6}$ \\
\hline $\begin{array}{l}8 \text { molecules per } \\
\text { bacterium }\end{array}$ & $\begin{array}{l}\text { Ery } 6 \\
\text { SM }\end{array}$ & $\left.\begin{array}{l}4.7 \times 10^{6} \\
3.5 \times 10^{6}\end{array}\right\}$ & $8.2 \times 10^{6}$ \\
\hline
\end{tabular}

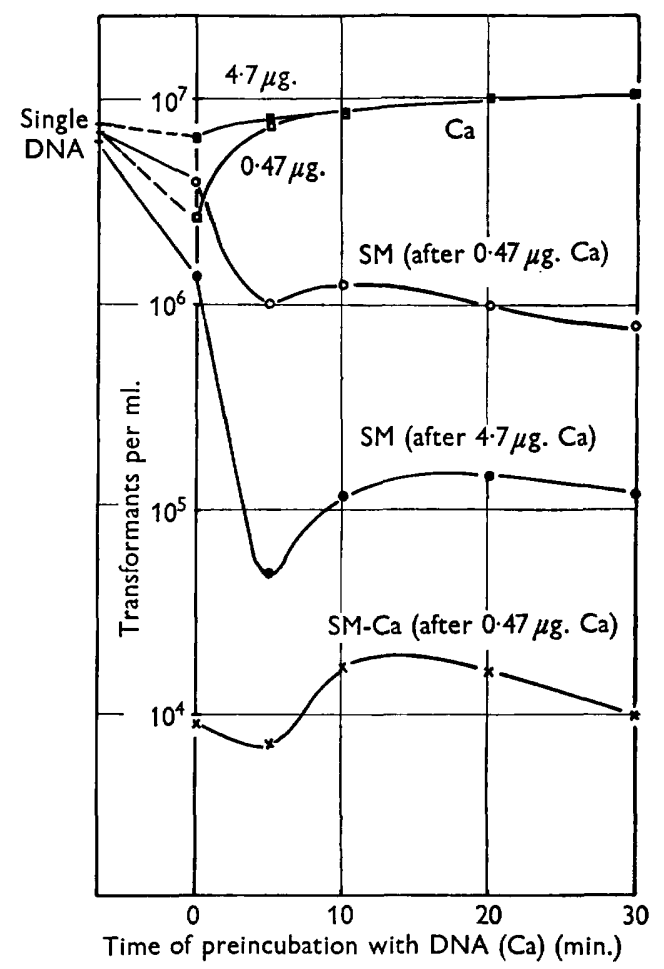

Fig. 3. Influence of preincubation of competent bacteria of Haemophilus influenzae strain Rd with excess DNA(Ca) on subsequent transformation with excess DNA(SM). DNA(Ca) was pipetted at time zero into a series of tubes containing the competent bacteria. Ca-transformants were scored and DNA(SM) was added at the indicated intervals. SM-, Ca-, and (SM + Ca)-transformants were assayed $5 \mathrm{~min}$. later. Zero-time data were obtained by adding a mixture of the two DNAs to the bacteria. The competition effect was demonstrated by adding only DNA(SM) to a control suspension. 
competent cultures. The results of this experiment and of another one in which the DNA(Ca) concentration had been increased ten times are shown in Fig. 3. The numbers of Ca-transformants scored before addition of DNA(SM) were always equal to those determined after addition of the DNA(SM). The data warrant the following conclusions. (1) Absorbed DNA is fixed in less than 5 min., i.e. it can no longer be competed against. (2) A competent culture has a given capacity with regard to the absorption of DNA. (3) Under the conditions employed, the remaining transformability of the bacteria after addition of DNA drops little with time.

\section{Anaerobic period at $\mathbf{3} 7^{\circ}$}

So far, a competent bacterium has been defined as one which can undergo transformation when brought in contact with the proper DNA. It is clear from the preceding sections that a sizable fraction of anaerobically held bacteria develop competency during as little as $5 \mathrm{~min}$. at $\mathbf{3 0 - 3 7 ^ { \circ }}$ when diluted into saline. Since exposure of recipient bacteria to DNA routinely occurs under conditions which permit the development of competency, we had to block the latter process. This was done by first adding $10 \mu \mathrm{g}$. $/ \mathrm{ml}$. of chloramphenicol to the bacteria. In the following sections, then, we consider a bacterium competent if it can undergo transformation in the presence of chloramphenicol.

Length of anaerobic period. We should point out first, that in this phase oxygen is not completely excluded from the bacteria as the $15 \mathrm{ml}$. of culture are incubated in a standing $18 \mathrm{~mm}$. tube plugged with cotton wool. The cell concentration being over $10^{9}$, we believe, however, that oxygen is used up much faster in most of the suspension than its supplementation by diffusion into the culture. This justifies in our opinion the term anaerobic.

The anaerobic period is necessary for the subsequent development of competency, but during the period itself very few bacteria become transformable. Perhaps one can best describe what happens as a sensitization. Logarithmic-growth-phase bacteria $\left(15 \mathrm{ml}\right.$.) were incubated in an $18 \mathrm{~mm}$. tube at $37^{\circ}$. At indicated intervals, $0 \cdot 2 \mathrm{ml}$. samples were added to: (1) $1.6 \mathrm{ml}$. of saline and incubated at $30^{\circ}$ to make them competent and (2) $1.8 \mathrm{ml}$. of saline containing chloramphenicol and excess DNA(SM) to measure the transformable bacteria present. To the first series of tubes, the antibiotic and DNA were added after $60 \mathrm{~min}$. The transformants scored after 5 min. are plotted in Fig. 4. The lower curve gives the numbers of competent bacteria present in the anaerobically held suspension while the upper curve gives the corresponding numbers of sensitized bacteria, i.e. bacteria which became competent after a further incubation in saline-broth.

Loss of competency and of sensitization. Competency and sensitization seem to be two different cell conditions. This is further demonstrated by two experiments designed to measure the loss of either one upon growth. First, sensitized bacteria (anaerobically held for $75 \mathrm{~min}$.) were diluted four times with fresh broth and shaken at $37^{\circ}$. At intervals, $0.2 \mathrm{ml}$. samples were diluted ten-fold in saline, incubated during $60 \mathrm{~min}$. at $30^{\circ}$ to make all sensitized bacteria competent and exposed to excess DNA(SM) in the presence of chloramphenicol. Secondly, competent bacteria, derived from the originally sensitized culture, were diluted ten-fold with fresh broth and shaken at $37^{\circ}$. At intervals, $0.2 \mathrm{ml}$. amounts were added to $1.8 \mathrm{ml}$. of saline 
containing chloramphenicol and excess DNA. Both cultures grew with the normal division rate of once every $30 \mathrm{~min}$. Transformants were scored and their numbers plotted relative to the initial ones (Fig. 5). It can be seen that sensitization is reduced ten-fold over a 60 min. period while competency drops much faster. The dilution itself into fresh broth did not cause any significant loss of either condition. There is no indication that competency or sensitization is related to the normal growth cycle of the bacteria.

Development of competency in broth. The number of competent bacteria in an anaerobically held suspension is usually very small, i.e. transformation frequencies range from $10^{-5}$ to $10^{-4}$. Upon renewed shaking, sensitization is lost but competency increases relatively much. This is shown in Table 5. A sensitized (anaerobically

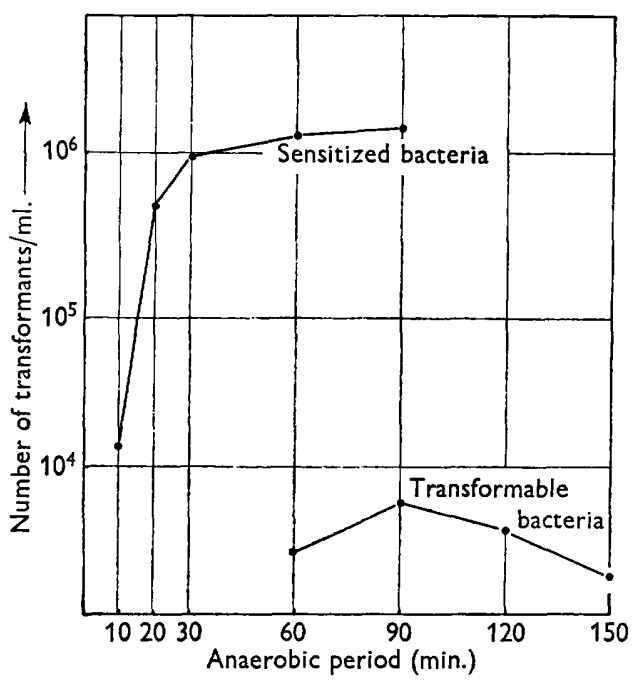

Fig. 4

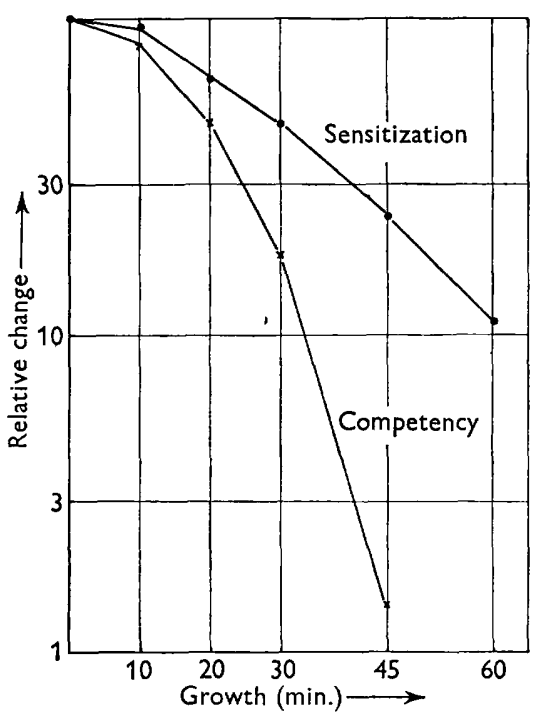

Fig. 5

Fig. 4. Development of competency and of sensitization in Haemophilus influenzae strain Rd during the anaerobic period. $15 \mathrm{ml}$. of logarithmic-growth-phase bacteria were incubated in a standing $18 \mathrm{~mm}$. tube immersed in water at $37^{\circ}$. At times, $0.2 \mathrm{ml}$. samples were withdrawn and added to (1) $1.8 \mathrm{ml}$. of saline containing chloramphenicol and excess of DNA(SM) (determination of competent bacteria) and (2) $1.6 \mathrm{ml}$. of saline followed by incubation at $30^{\circ}$ during $60 \mathrm{~min}$. after which $0.1 \mathrm{ml}$. of chloramphenicol solution and $0.1 \mathrm{ml}$. of DNA(SM) solution were added (determination of sensitized bacteria). Transformants were in both cases scored after $5 \mathrm{~min}$. Competent and sensitized bacteria at time zero: less than $10^{3}$ per ml.; transformants at times 30 and $180 \mathrm{~min}$.: less than $10^{3}$ per $\mathrm{ml}$.

Fig. 5. Loss of sensitization and of competency upon growth of a sensitized, respectively, competent culture of Haemophilus influenzae strain Rd. A sensitized (anaerobically held) culture was diluted in fresh broth and shaken at $37^{\circ} .0 .2 \mathrm{ml}$. amounts were diluted at the indicated times into $1.6 \mathrm{ml}$. of saline and incubated during $60 \mathrm{~min}$. at $30^{\circ}$ after which chloramphenicol and excess of DNA(SM) were added. The transformants scored after $5 \mathrm{~min}$. give the loss in sensitization. A highly competent culture derived from the sensitized one (in fact, the zero-time one) was also diluted in fresh broth and shaken at $37^{\circ}$. $0.2 \mathrm{ml}$. samples were at times added to $1.8 \mathrm{ml}$. of saline containing chloramphenicol and excess DNA(SM). The transformants scored after 5 min. give the loss of competency of the culture. Initial transformation frequencies (after dilution); sensitization, $3.9 \times 10^{-2}$ and competency, $3.0 \times 10^{-2}$. Competent bacteria at $60 \mathrm{~min}$. had dropped to less than $0.01 \%$. 
held) suspension was again shaken at $\mathbf{3} 7^{\circ} . \mathbf{0 \cdot 2} \mathrm{ml}$. amounts were added at indicated times to (1) saline plus chloramphenicol plus excess DNA(SM) to measure the competent bacteria present, and (2) saline alone to measure the sensitized bacteria present. The latter tubes were incubated at $30^{\circ}$ during $60 \mathrm{~min}$. after which chloramphenicol and DNA were added. The numbers of competent bacteria increased to more than $10^{6}$ per $\mathrm{ml}$. but the actual transformation frequencies did not exceed $5 \times 10^{-3}$ since the total number of viable centres had also increased. This is a low value compared to the ones routinely obtained. The second series of tubes gave the loss in sensitization (compare with data in Fig. 5).

Table 5. Development of competency and simultaneous loss of sensitization (presented as transformation frequencies calculated) during renewed growth of an anaerobically held (sensitized) suspension of Haemophilus influenzae strain $R d$

The suspension was again shaken at $37^{\circ}$ The numbers of transformable bacteria were determined by adding $0.2 \mathrm{ml}$. of culture to $1.8 \mathrm{ml}$. of saline containing chloramphenicol and excess DNA(SM). Transformants were scored after 5 min. The numbers of sensitized bacteria were determined by adding $0.2 \mathrm{ml}$. of culture to $1.6 \mathrm{ml}$. of saline followed by incubation at $30^{\circ}$ during $60 \mathrm{~min}$. after which chloramphenicol and excess DNA were added. Transformants were scored after $5 \mathrm{~min}$. The total numbers of viable centres per $\mathrm{ml}$. were also determined so that the results can be given as frequencies.

$\begin{array}{ccc}\begin{array}{c}\text { Time of growth } \\ \text { (min.) }\end{array} & \begin{array}{c}\text { Competency } \\ \text { (transf. frequ.) }\end{array} & \begin{array}{c}\text { Sensitization } \\ \text { (transf. frequ.) }\end{array} \\ 0 & 4.2 \times 10^{-4} & \mathbf{3 . 6} \times 10^{-2} \\ 15 & 4.3 \times 10^{-3} & 1.9 \times 10^{-2} \\ 30 & 4.5 \times 10^{-3} & 9.5 \times 10^{-3} \\ 45 & 1.9 \times 10^{-3} & 2.9 \times 10^{-3}\end{array}$

\section{Aerobic period}

The bacterial concentration at which aerobic growth is stopped is not very critical between $6 \times 10^{8}$ and $2 \times 10^{9} \mathrm{per} \mathrm{ml}$. We have found optimal transformation frequencies when aeration was stopped at about $10^{9}$ viable centres per ml. During the following anaerobic period turbidity increases by about $50 \%$ while the viable count goes up a little more. We have also grown bacteria in Levinthal stock instead of broth and obtained nearly equal results.

\section{Absorption of $D N A$}

Competent bacteria obviously absorb DNA but do growth-phase or sensitized ones? We found out that they do not. Growth-phase bacteria and sensitized ones $(0.4 \mathrm{ml}$.) were added to $1.6 \mathrm{ml}$. of saline containing chloramphenicol. To eight tubes in each series, $0.001 \mu \mathrm{g} . / \mathrm{ml}$. of $\mathrm{DNA}(\mathrm{SM})$ was added and the suspension shaken at room temperature. Eight competent cultures $(0 \cdot 2 \mathrm{ml}$. of sensitized bacteria diluted into saline and incubated at $30^{\circ}$ after which chloramphenicol was added) were also exposed to this amount of DNA. Two tubes of each series were each time analysed for transformants after 10, 20,30 and $40 \mathrm{~min}$. and then centrifuged. The supernatants were stored overnight at $\mathbf{- 2 5 ^ { \circ }}$. They were analysed the following day for remaining DNA by adding one volume each from both duplicate tubes to 2 vols. of competent $R d$ bacteria which had been concentrated four times by centrifugation and resuspending into saline. Transformants were scored after $20 \mathrm{~min}$. 
The numbers of markers (activity of the DNA) remaining in the supernatants are presented in Table 6. We conclude from these data and from similar ones obtained in repeated experiments, that little, if any, DNA is absorbed by either growth-phase or sensitized bacteria.

This was confirmed by transforming ( 1 ) a pure suspension of competent bacteria $2 \times 10^{8}$ per ml. (2) the same suspension with $2 \times 10^{8}$ per ml. of sensitized bacteria added, and (3) the same suspension with $4 \times 10^{8}$ per ml. of sensitized bacteria added; all with $0.001 \mu \mathrm{g} . / \mathrm{ml}$. of DNA(SM) during $20 \mathrm{~min}$. and in the presence of chloramphenicol. The numbers of transformed cells observed were $2.9 \times 10^{5}$, $3 \cdot 2 \times 10^{5}$ and $3 \cdot 2 \times 10^{5}$ per sample, respectively. Clearly, the sensitized bacteria did not influence the response to DNA by the competent ones.

Table 6. Absorption of limiting amounts of DNA in the presence of chloramphenicol by growing bacteria, by sensitized ones and by competent ones

DNA concentration: $0.001 \mu \mathrm{g} . / \mathrm{ml}$. Bacteria concentration: growth-phase and sensitized: $4 \times 10^{8}$; competent: $2 \times 10^{8}$ per ml. The bacteria were mixed with the DNA in saline containing $10 \%$ broth and chloramphenicol. They were spun down after intervals after transformants had been scored. The supernatants were mixed with known numbers of competent bacteria, shaken during $20 \mathrm{~min}$. and thereafter transformants were scored. Their numbers are given as markers per ml. (activity of the DNA) in the fourth column. A fresh solution containing $0.001 \mu \mathrm{g} . / \mathrm{ml}$. of DNA served as a control (no DNA absorbed).

\begin{tabular}{|c|c|c|c|c|}
\hline Culture & $\begin{array}{c}\text { Exposure } \\
\text { time (min.) }\end{array}$ & $\begin{array}{l}\text { Transformants } \\
\text { per ml. }\end{array}$ & $\begin{array}{c}\text { Markers/ml. in } \\
\text { supernatant }\end{array}$ & $\begin{array}{c}\text { Absorbed } \\
\text { DNA (\% } \\
\text { of control) }\end{array}$ \\
\hline $\begin{array}{l}\text { Control (no } \\
\text { cells) }\end{array}$ & 一 & - & $2 \cdot 7 \times 10^{5}$ & - \\
\hline Growth phase & $\begin{array}{l}10 \\
20 \\
30 \\
40\end{array}$ & $\begin{array}{l}\text { Less than } 10^{8} \\
\text { Same } \\
\text { Same } \\
\text { Same }\end{array}$ & $\begin{array}{l}3 \cdot 2 \times 10^{5} \\
2 \cdot 2 \times 10^{5} \\
2 \cdot 4 \times 10^{5} \\
2 \cdot 4 \times 10^{5}\end{array}$ & $\begin{array}{r}-18 \\
19 \\
11 \\
11\end{array}$ \\
\hline Sensitized & $\begin{array}{l}10 \\
20 \\
30 \\
40\end{array}$ & $\begin{array}{l}\text { Less than } 10^{3} \\
\text { Same } \\
\text { Same } \\
\text { Same }\end{array}$ & $\begin{array}{l}2.8 \times 10^{5} \\
2.5 \times 10^{5} \\
1.9 \times 10^{5} \\
2.6 \times 10^{5}\end{array}$ & $\begin{array}{r}-4 \\
8 \\
30 \\
4\end{array}$ \\
\hline Competent & $\begin{array}{l}10 \\
20 \\
30 \\
40\end{array}$ & $\begin{array}{l}2.2 \times 10^{5} \\
2.0 \times 10^{5} \\
2.4 \times 10^{5} \\
2.8 \times 10^{5}\end{array}$ & $\begin{array}{l}5.5 \times 10^{4} \\
5.3 \times 10^{4} \\
7.0 \times 10^{4} \\
1.8 \times 10^{4}\end{array}$ & $\begin{array}{l}79 \\
80 \\
74 \\
93\end{array}$ \\
\hline
\end{tabular}

\section{DISCUSSION}

It may seem confusing to speak of highly competent (transformable) cultures which show transformation frequencies of ('only') $1-5 \%$. But the point is that purified DNA solutions contain 'broken up' bacterial DNA. Estimates in this respect are that one bacterial DNA unit splits into 50-100 particles with a molecular weight of 15-30 million (Goodgal \& Herriott, 1957; Stuy, 1961 $a$ ). We believe that only one of those particles carries a given marker. Consequently, bacteria which have picked up genetically unmarked DNA, may be transformed, i.e. they may incorporate this DNA. Since they do not change genetically as a consequence, there is no simple way of telling whether this happens. By employing two or more unlinked markers and by measuring the transformation frequencies of single markers and their doubles, one can compute the fraction of bacteria which would have been 
transformed after absorption of marked DNA. This fraction is close to one in highly competent cultures, i.e. cultures showing transformation frequencies of one per cent or more (Stuy, 1961 $a$; Goodgal \& Herriott, 1961). As a consequence, we feel confident to state that the actual number of competent bacteria is roughly 100 times the number of transformants observed in cases where their frequencies are lower than one per cent.

We have tried to make clear that it takes three successive treatments in order to obtain highly transformable cultures of $H$. influenzae strain Rd. This observation seems to disagree with a report by Goodgal \& Herriott (1961) who state that the anaerobically held bacteria (in our study: sensitized) are competent. We believe that in their experiments bacteria may have become competent during the relatively long exposure to DNA. To prevent this, we added chloramphenicol.

The development of competency by sensitized bacteria shows surprisingly few requirements, as was first established by Grace Leidy and co-workers (in the Press). It is not so surprising that it is blocked by growth inhibitors. Unfortunately, this reveals very little about the nature of the process.

Absence of competency goes along with incapability of absorbing DNA. We would like to know whether this incapability is in fact the reason why most bacteria are not transformable. Absorption of DNA seems to be energy-requiring as it is blocked by dinitrophenol or arsenate. This suggests the participation of an enzyme system. Untransformable bacteria, perhaps, lack such a system.

Competency and sensitization are retained quite well by the bacteria in the absence of growth. One may wash the bacteria without destroying much of either condition. The absorption of small amounts of DNA has little or no effect on the competency of the bacteria involved. Excess amounts of DNA still leave 'some room' for subsequently added DNA. The extent of this is dependent upon the amount of the first DNA which fact indicates that we are indeed dealing with a relatively simple DNA saturation effect. We wondered about the observed speed with which the first DNA was fixed by recipient bacteria, i.e. it could no more be competed against after $5 \mathrm{~min}$. or less. Recent experiments (unpublished) have revealed that the DNA had not yet been crossed in (recombination with the bacterial chromosome) by that time. We tend to believe, therefore, that the absorbed DNA is quickly and firmly bound by the available intracellular sites. In a later stage, it recombines with the bacterial DNA.

I wish to record my appreciation to Miss Joke Bloemendal who ably assisted in carrying out the experiments.

\section{REFERENCES}

Avery, O. T., Macleod, C. M. \& McCarty, M. (1944). Studies on the chemical nature of the substance inducing transformation of pneumococcal types. Induction of transformation by a desoxyribonucleic acid fraction isolated from pneumococcus Type III. J. exp. Med. 79, 137.

Fox, M. S. \& Hoтchкiss, R. M. (1957). Initiation of bacterial transformation. Nature, Lond., 179, 1322.

Goodgal, S. H. \& HerriotT, R. M. (1957). Studies on transformation of Haemophilus influenzae. In The Chemical Basis of Heredity, p. 336. Ed. by W. D. McElroy \& B. Glass. Baltimore: Johns Hopkins Press. 
Goodgal, S. H. \& HerriotT, R. M. (1961). Studies on transformation of Haemophilus influenzae. I. Competence. J. gen. Physiol. 44, 1201.

HotchKIss, R. D. (1954). Cyclical behaviour in pneumococeal growth and transformability occasioned by environmental change. Proc. nat. Acad. Sci., Wash. 40, 49.

STUY, J. H. (1960). Studies on the mechanism of radiation inactivation of microorganisms. VI. X-ray-induced breakdown of deoxyribonucleic acid in Haemophilus influenzae and in other bacteria. J. Bact. 79, 707.

STUY, J. H. (1961 a). Radiation inactivation of intracellular transforming deoxyribonucleic acid. Doctoral thesis. Utrecht (reprints available).

STUY, J. H. (1961 b). Studies on the mechanism of radiation inactivation of microorganisms. VIII. Inactivation of intracellular multiply-marked Haemophilus influenzae deoxyribonucleic acid by high-voltage electrons. Rad. Res. 15, 45. 